MARRIAGE AND SLAVERY

IN EARLY ISLAM 



\title{
MARRIAGE AND SLAVERY IN EARLY ISLAM
}

\author{
Kecia Ali
}

Harvard University Press

Cambridge, Massachusetts

London, England 2010 
Copyright $\odot 2010$ by the President and Fellows of Harvard College

All rights reserved

Printed in the United States of America

Library of Congress Cataloging-in-Publication Data

Ali, Kecia.

Marriage and slavery in early Islam / Kecia Ali.

p. $\mathrm{cm}$.

Includes bibliographical references and index.

ISBN 978-0-674-05059-4 (alk. paper)

1. Marriage (Islamic law) 2. Concubinage (Islamic law)

3. Slavery (Islamic law) I. Title.

KBP542.35.A45 2010

$297.5^{\prime} 77-\mathrm{dc} 22 \quad 2010000937$ 